\title{
Revealing Pre-service Teachers' Reading Skills by Utilizing CEFR in their Self-assessment
}

\author{
${ }^{1}$ Raquel Da Silva Lemos, ${ }^{2}$ Elysa Hartati* \\ Universitas Mercu Buana Yogyakarta \\ *Corresponding Author \\ Email: elysa@mercubuana-yogya.ac.id
}

\begin{abstract}
An English teacher should meet the standard English skills requirement since proficiency constitutes the foundation of non-native English teachers' professional confidence. This research aims to measure the pre-service teachers' reading skills by using CEFR level and to investigate pre-service teachers' awareness regarding their reading skills as their preparation as future English teachers. The study involved 40 (forty) students from the English program in a private University in Yogyakarta, and used Descriptive Mixed method to collect the data. The researcher used the questionnaire for the students' self-assessment, and the EF SET test to assess their reading skill level. The result of the questionnaire obtained shows $20 \%$ of students are in level A1, 25\% are in level A2, 25\% are in level B1, $12 \%$ are in level $B 2,10 \%$ are in level $C 1,8 \%$ are in the level $C 2)$. The test result shows $17 \%$ of the students are in level A1, 25\% in level A2, 25\% in level B1, 20\% are in level B2, $8 \%$ are in level C1, and $5 \%$ are in the level C2. Six students joined the survey, of which 3 (three) rated themselves at a reading level above the result obtained on the test, and 3 (three) others rated themselves at a level lower than the result they got on the test. The result of this research showed that pre-service teachers should improve in English language proficiency and self-assessment. This knowledge expects to be used as information to those involved in the Educational field.
\end{abstract}

Keywords: Pre-service teacher, Reading skills, CEFR, Self-assessment

\section{INTRODUCTION}

The demand for learning English increases considerably. According to Renandya in Bui (2016), proficiency in the English language can bring numerous social and economic benefits, e.g., higher employability, increased international mobility, and greater access to information and education. Although, in lots of parts of the world, the demand for proficient L2 speakers of English often surpasses the supply. Renandya in Bui (2016) also says, "This is true in many places in the Asian region where most of our students often leave schools and universities with less than a satisfactory level of proficiency in the English language". Therefore, this research intends to discuss the need of the English language teacher be well prepared to become a professional who is able to prepare their students to attend the demand existent.

The low level of English proficiency also involves Indonesia. The 2020 EPI (English Proficiency Index) data show that Indonesia ranked 74th out of 100 countries globally and 15th out of 24 countries in Asia. With an average score of 453, Indonesia falls under the 'low proficiency band' category (https://www.ef.sg/epi/regions/asia/). Fresh graduates from teacher education colleges in Indonesia show varying levels of proficiency. Eventhough, some teacher education colleges require their student teachers to demonstrate evidence of 
proficiency before graduation. However, others let their students exit the program, although they may not have met the proficiency standard to teach English in schools (Renandya, 2018). Based on research, the teachers' low English proficiency in the education process itself is one of the reasons that cause low proficiency among students in Indonesia. Thus, having proficient teachers as a model for their students are needed to meet the existing demand as the agents of change.

According to Lange cited in Eslami and Fatahi (2008), language proficiency constitutes the foundation of non-native English teachers' professional confidence. Language proficiency is one of the critical components that make up an experienced language teacher who can transmit their knowledge. Another reason an English teacher should meet the standard requirement of English necessary skills such as listening, speaking, reading, writing because he/she will use them to communicate with the students.

Regarding the importance of teachers' English proficiency, the university has a crucial role to play. A teacher education program's objective is to provide individuals with professional and personal skills needed in school and other learning contexts (Unesco, 2020). Teachers must provide content knowledge, develop skills, and promote attitudes to allow students to reach their potential. Therefore, the university Education department has to ensure that they provide the materials and opportunities to help their students reach the needed proficiency as a future English teacher.

In teaching English, there are four main basics Language skills: listening, speaking, reading, and writing. The skills work in pairs: reading and listening are a receptive skill while speaking and writing are a productive skill. The deficiency of receptive abilities such as listening and reading will interfere with the productive skills that are speaking and writing. Therefore, the four skills play a relevant role in the achievement of becoming fluent in a language. All these things are significant parts for those interested in being well prepared for the job market (Tol, 2016). In another word, it is expected that the students receive the appropriate teaching to help them develop all the four needed skills.

Since writing is a skill influenced by reading, the importance of a good development of reading ability cannot be ignored. On the word of Aktifa (2015), reading is also crucial and indispensable for the students because their success depends on the more significant part of their ability to read. If their reading skill is low, they are very likely to fail in their study or at least they will have difficulty in making progress. On the other hand, if they have excellent reading ability, they will have a better chance to succeed in their study. By reading, students can increase their knowledge and face new information in the text. Therefore, teacher training colleges will be able to train their students in reading skills.

Reading skills is the ability to read particular kinds of reading. For example, most reading course-books will include activities devoted to skimming, scanning, reading for main ideas, and reading and making inferences (Richards, 2015). Concerning the necessities of well-prepared teachers, this article intends to investigate the Reading Skills of English Education students' real condition in the English Program by Using the CEFR (Common European Framework of Reference). The CEFR provides a usual basis for elaborating language syllabus, curriculum, guidelines, examinations, textbooks, e.g., across Europe. It describes which language learners have to learn to use it for communication and what 
knowledge and skills they have to expand into acting effectively. Also, the CEFR is available and recognized in all European countries. It is still increasingly referred to national or regional policy levels in many countries in Asia, the Middle East, Latina America, and Australasia. It is an International level for describing language capacity. It portrays language ability on a six-point scale, from A1 (beginners) to $\mathrm{C} 2$ for those who have become proficient in a language (Cambridge, 2019). The CEFR provides a score description of each level A1 Beginner can understand familiar names, words, and straightforward sentences, such as notices and porters or catalogs. A2 Elementary can read concise, and simple texts. It can find specific, predictable information in simple everyday material such as advertisements, prospectuses, menus, and timetables and can understand short, simple personal letters. B1 Intermediate Can understand texts that consist mainly of high frequency or job-related language and can also understand the description of events, feelings, and wishes in personal letters. B2 Upper Intermediate can read articles and reports concerned with contemporary problems in which the writers also adopt particular attitudes or viewpoints and understand modern literary prose. C1 Advanced can understand long and complex factual and literary texts, appreciating distinctions of style and understanding technical articles and more comprehensive technical instructions, even when they do not relate to their field. C2 Proficient can easily read all written language forms, including abstract, structurally or linguistically complex texts such as manuals, technical articles, and literary works. For reading comprehension, the CEFR is designed to measure the ability to read and understand various topics that include reading correspondence, reading for orientation, reading for information, argument, and reading instructions(Cambridge, 2019).

Besides investigating the pre-service teacher's reading skill, this research made a simple study about the pre-service teachers' metacognitive awareness of their reading skills. According to Flavell, quoted in Hughes (2019), metacognitive awareness is a person's awareness regarding their cognitive ability in processing or learning certain information or data. A person regards being aware of his metacognitive ability when they can tell that they are better at studying A than studying B. In other words, metacognitive awareness is one's knowledge of how good or bad is the student's learning ability. Also, in agreement with Pintrich cited by Hermayawati (2020, p.189), metacognitive is related to cognition in general and to the awareness and self-knowledge of cognition. It has both educational and psychological benefits and helps students be more knowledgeable and responsible for their cognition. In summary, metacognition is the awareness that the individual has about his cognitive ability. For instance, when reading a text, he can discern the level of difficulty and has the ability to change the reading strategy. Possessing good metacognition awareness is very important for a student to be successful in their academic pursuit. Students not only need to understand the content, but they also need to think and respond critically about what the text is. It is in line with the demand of the curriculum applied for college-level that they need to have HOTS (Higher Order Thinking Skills) which can analyze, evaluate, and create. This work aims to show how it is important for a future English teacher to be aware of their reading level then be prepared to help their students reach proficiency.

Furthermore, to achieve awareness, students should develop the ability of self-assessment. In line with Klenowski (1995) quoted by Ross (2006, p.1), the definition of self-assessment is "the assessment or judgment of the 'value' of 
someone's performance and also the identification of their strengths and weaknesses to improve someone's learning results. " This is possible because such awareness will help the student identify their weakness and strength and then build a set of strategies and make effective decisions in determining their learning style to improve the skill that they want to master (Rivers et al., 2020). Thus, by underlining the importance of the self-assessment to deal with the pre-service teachers' reading skill, the objectives of this research are formulated (1) to measure the pre-service teacher reading skill by using CEFR level and (2) to investigate the pre-service teacher's awareness regarding their reading skill as their preparation as future English Teacher.

\section{METHOD}

This study took place at a private university in Yogyakarta. The subjects were 40 (forty) universities student majoring in English Language Education study program, ages between 18 to 37 years old; ten of the students were male, and thirty of the students were female Nine of the students were freshmen, ten were in the third semester, eleven of them were in the fifth semester, 10 of them are senior. The target respondents were students' pre-service English teachers. This study aims to discover and show proficiency in the reading of the students of the English program. As of the outcome obtained in this research, it was possible to perceive whether students have reached the proficiency necessary to become an excellent professional in teaching English. Moreover, based on that information, it is necessary to seek the ways to help students achieve their goals.

This research used a descriptive mixed method. Descriptive analysis is used to obtain information concerning the current status of the phenomena and describe "what exists" to variables or conditions in the situation. As stated by Creswell (2012), mixed-method research deals with quantitative survey data. Then it is followed up with qualitative interview data to help explain the initial quantitative results. Moreover, the sampling and approach to selecting participants used in this research were purposeful, and based on Patton (1990, p.169) cited by Creswell (2012, p.206), the analysis term used for qualitative sampling is a purposeful sampling. In purposeful sampling, researchers designedly choose people and sites to find out or perceive the central development. The quality utilized in selecting participants and sites is whether or not they are "information-rich."

The quantitative data of this research was obtained through the EF SET TEST (CEFR) and Questionnaire. This test shows the pre-service teacher's reading skill through a leveling system and answer the pre-service teacher's reading skill. The EF SET Test is a reading English test with the leveling system aligned with CEFR and was currently the only test that can measure all English skills from beginners to fluent within the standards required by CEFR. It also supplies the English Proficiency Index (EF EPI) data, an annual ranking of countries by their English level. The test was shared through the college's WhatsApp group and individual students because it was more useful to get the students' responses.

Since the Covid-19, the students have not been gathering together; therefore, the questionnaire was applied through the google form link: https://forms.gle/7ywLT3XaH4SqnnUZ7 which was then shared with the groups of college. The questionnaire consisted of 8 questions. Seven questions were borrowed from the 'Background Questionnaire for Reading Skills' (Mcmillion, 2009); 
questions related to the students' reading habits and takes self-assessment from the "what can-do statements" from the CEFR reading score description. The data were then analyzed quantitatively by having the percentages of the responses gathered.

Meanwhile, the interview was to explain the pre-service teacher's awareness of their reading skills. Some students had different results between their selfassessment and their reading test. Six students were picked purposively among the respondents who had different self-assessment results and the EF SET test score. The interview contained five questions to determine why the students choose their reading skill level different from what they got from the reading test result. The data obtained from the interview were analyzed descriptively through the answers employed to figure out the gap between their reading self-assessment and the reading test.

\section{RESULTS AND DISCUSSION}

This work was intended to find out how the students` proficiency in reading skills by using CEFR self-assessment. Furthermore, to what extent are the students' awareness of reading skill as their preparation to be a future English teacher.

\section{The student's self-assessment on reading skills}

The students were assessed through the rubric of measurement on reading provided by CEFR to measure the students' awareness of reading skills, which had some levels: A1, A2, B1, B2, C1, and C2. The score description was then wrapped into a questionnaire, as shown in Figure 1, to be filled out by 40 (forty) respondents in the English Language Education Study Program. The questionnaire's purpose was to find the students' perception of their English reading skills to become an English Teacher. This perception is essential to determine the extent to which the students' awareness of reading skills through their judgment.

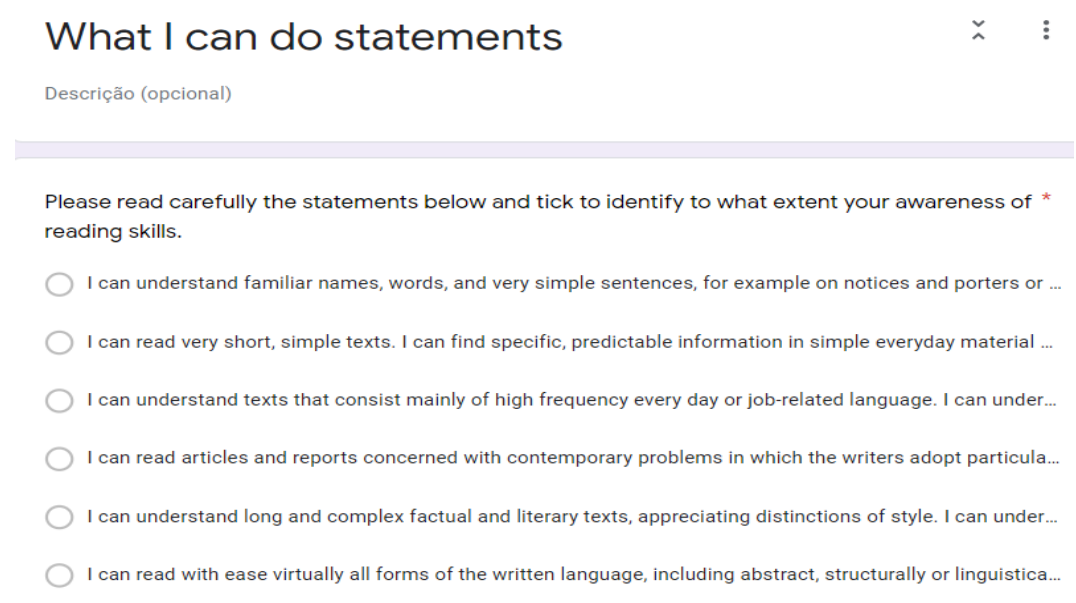

Figure 1. The Questionnaire based on the CEFR rubric on reading skills 


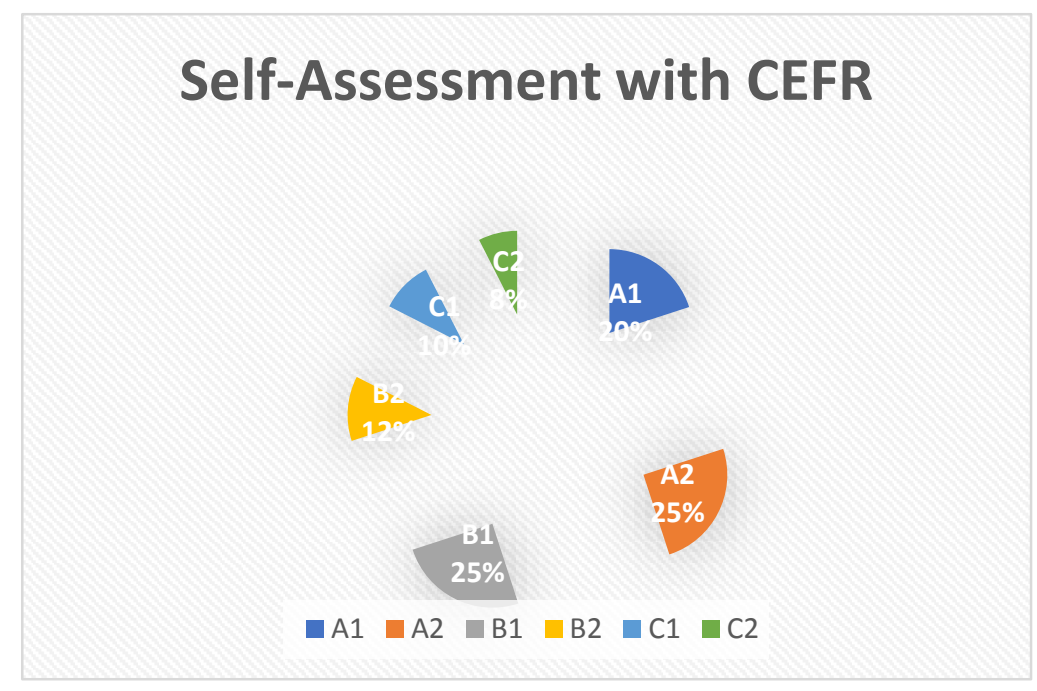

Figure 2. The result of self-assessment CEFR

The results of questionnaires administered to students can be interpreted based on the data shown in Figure 2. There were 20\% (8 students) that identify themselves in the level (A1) Beginner, and there were 25\% (10 students) said that they are in the level (A2) Elementary. Meanwhile, there were 25\% (10 students) who stated themselves (B1) Intermediate, and here were $12 \%$ (5 Students) got (B2) Upper-intermediate. Moreover, 10\% (4 students) recognized themselves (C1) Advanced, and there were 8\% (3 students) of them in (C2) Proficient. This evaluation was what the respondents answered based on their perception of their reading skills. Most of the students scored themselves on $\mathrm{A} 2$ and $\mathrm{B} 1(25 \%=\mathrm{A} 1$ and $25 \%=\mathrm{B} 1$ ) representing $50 \%$, and $42 \%$ of the students scored themselves between $\mathrm{A} 1, \mathrm{~B} 2$, and $\mathrm{C} 1 ; 20 \%$ of them got $\mathrm{A} 1 ; 12 \%$ of them got $\mathrm{B} 2 ; 10 \%$ of them got $\mathrm{C} 1$. Only $8 \%$ of the students scored themselves on $\mathrm{C} 2$, which the English teacher should achieve.

Among forty students who participated in the self-assessment, nine students were in the first semester. Among them, three students rated themselves with the average A1. One of them evaluate him/herself as A2, and two among them as B1, one of the students $\mathrm{C} 1$, and finally, two students considered themselves in the highest proficiency $\mathrm{C} 2$. Considering these students are first-year students to the English Program, there was a huge possibility that those who have not yet reached C2 will complete college with this level of proficiency. Their success depend on their effort and how much they dedicate themselves to achieving their goal and the English language program of the teaching quality.

Ten students were in the third semester. Among them, two students rated themselves with the average A1. Two of them evaluated themselves as A2, and three among them as B1. One student rated him/herself on B2, two of them rated themselves on $\mathrm{C} 1$, and no one considered themselves in the highest level C2. Since they are in the third semester of the English Program, they have a good chance of reaching the $\mathrm{C} 2$, which an excellent professional should achieve.

Eleven students were in the fifth semester. Among them, two students rated themselves with the average A1. Two of them evaluate themselves as A2, and two among them as B1, four of the students B2. There was no $\mathrm{C} 1$, and one of the students scored him/herself in the highest level of proficiency. In the fifth semester, 
they are getting closer to be graduated, then to achieve their goal of becoming proficient, they should study harder, and the English program should look forward to helping their students succeed, especially in their reading proficiency.

Ten students were in the seventh semester. Among them, one student rated $\mathrm{him} /$ herself with the average A1. Five of them evaluated themselves as A2, and two among them as B1, there was no students in B2, and one of them rated him/herself in $\mathrm{C} 1$, and no one of the students considered him/herself in the highest level of proficiency the $\mathrm{C} 2$. Since they are almost graduate, they have a huge chance to leave the university without reaching the highest English proficiency to be a wellqualified teacher. Consequently, the non-proficient teacher will negatively affect his students' lives because if they were not well prepared, they will also not prepare their students well.

\section{The students' reading skills test result}

The EFSET (CEFR) test was applied to get the students' reading skills and compare them with their self-assessment. The purpose of EF SET Test was to find the students' ability on English Reading Skills to compare with their perception about their level of Reading skills. This test result was necessary; to find out if their evaluation was according to the test result or not. The EF SET Test results administered to students are interpreted based on the data collected, and it is in figure 3: $17 \%$ (7) of the students got the level (A1). Furthermore, there were (25\%) 10 students the result revealed their level as an (A2). There were 25\% (10 students) of the test result was (B1). There were $20 \%$ (8 Students) between the respondents (B2) in the test. Among the students, $8 \%$ (3 students) got the score (C1). There were $5 \%$ (2 students) who got the highest score (C2). It was possible to observe that the majority of future teachers fall into categories A2 and B1. Simultaneously, the ideal would be that they would all be proficient in the reading skills and expect that prospective teachers can improve their level and reach proficiency to become qualified teachers and prepared to enhance the quality of English language teaching.

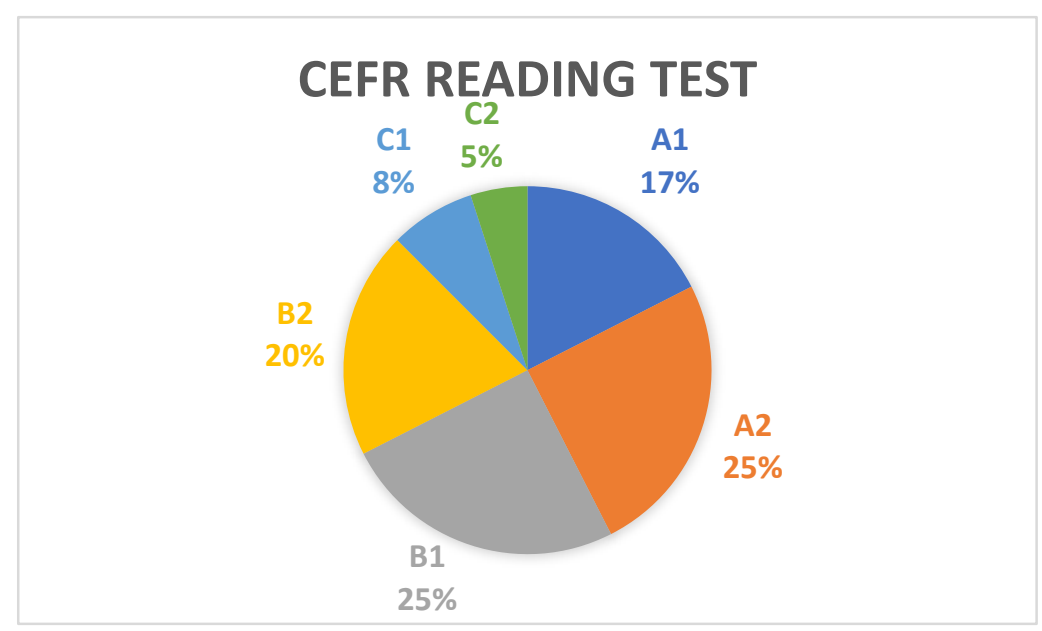

Figure 3.The Result of Students' Self -assessment based on CEFR Reading Skill 
Among the forty students who took the reading test, ten students evaluated themselves according to their level, and the other thirty students considered themselves at a different level from the one obtained in the test. Of the ten students who self-assessed at their level, one student was from the first semester, and the other nine students are three from the third, three from the fifth, and three from the seventh semester, respectively. Concerning the thirty students who rated themselves lower or higher than the result they obtained on the reading test, they are: From the first semester, five students rated themselves below their level, and three students above, which it was possible to realize that probably because first-year students in the English program, they still feel insecure about their level of proficiency. Of the students in the third semester, three students rated themselves below their level, and four students considered themselves above their average, which shows that they were not aware of their level of proficiency and still need to develop their selfassessment skills. Self-assessment is essential because, through it and the judgment of their performance, they can identify their strengths and weaknesses to improve their learning results. The students in the fifth semester, five students also rated themselves below the test average, while three students considered themselves above. In the seventh semester, three students rated themselves below their average level, and four students placed themselves above their level, which also shows the difficulty in defining their reading skill level. They need to increase their metacognitive awareness because it will help them be aware of how good or bad their learning ability is and improve their learning effectiveness and success in their academic pursuit.

\section{The students' interview result}

The self-assessment and the reading test were discussed based on the numerical results; therefore, students who evaluated themselves at a different level of what they got from the test result were selected to join the interview accurately to get more in-depth analysis.

Table 1. List of interview questions

\begin{tabular}{|l|l|}
\hline No. & \multicolumn{1}{|c|}{ Question Items } \\
\hline 1 & $\begin{array}{l}\text { Could you please explain the difference between self-assessment and EF SET } \\
\text { test scores? In your opinion, the score that you got from the EF SET test is } \\
\text { according to the real level of your reading skills or not? Explain why you said } \\
\text { yes, or why not. }\end{array}$ \\
\hline 2 & $\begin{array}{l}\text { After you joined the online test, how did you evaluate yourself now? (based } \\
\text { on the CEFR scale) Please explain why you evaluate yourself on this level. }\end{array}$ \\
\hline 3 & $\begin{array}{l}\text { In your opinion, would you evaluate the EF SET test as easy or hard level? } \\
\text { Why easy or why hard? }\end{array}$ \\
\hline 4 & $\begin{array}{l}\text { What was the most challenging part that you had faced on the previous test? } \\
\text { Why? }\end{array}$ \\
\hline 5 & What was the easiest part you had faced on the previous test? Why? \\
\hline
\end{tabular}

Among the forty students who participated in the self-assessment and reading test, six students were selected to join the interview, those who had the most significant different result from the test and questionnaire. Three of them scored themselves at a higher level than what they got from the test, and the other 3 scored themselves at a lower level. 
Student A was from the first semester, self-evaluated C1, and got A2 due to the reading test. She said that after joining the test, she realized that her real level was A2, according to what she got from the test. In her opinion, the test was hard, and she needs to improve her reading skills. The test time was too short, making it difficult for her to read all the text details. Moreover, the easiest part of the test was the first part because the text was simple.

Student B was from the fifth semester, self-evaluated C2, and got B1 in the reading test. He said that after joining the test and seeing his score, he realized that his level was B1, he can read and understand the short articles, and he needs to improve his reading skills self-assessment. According to him, the test was easy. The hardest part of the test was the last section, and the not tricky part was the first section.

The student $\mathrm{C}$ from the seventh semester self-assessed $\mathrm{C} 1$ and got $\mathrm{A} 1$ as a result of the test. She said that she disagrees with the reading test. In her opinion, her level between B2/C1 instead of A1 got from the test since she can understand the article, literary text. The test was a little bit hard for her, and from her perspective, the most challenging part was the third part and the simple section one.

The student D, from the first semester, self-assessed A2, and his test result was $\mathrm{C} 2$. He disagrees with the reading test result. The test was simple and not complex enough to testing his real level. However, the test helped him think profoundly and realized that his real level was B2 instead of A2, and he evaluated himself in the self-assessment. From his perspective, the test was not hard because most of the text used in the test was simple to understanding. The hardest part was the last section, and the easiest was the first section of the test.

The student E, from the third semester, self-assessed A1 and got C1 in the test. She was not sure whether she agrees with the test result or not. Since her perception, she still lacks vocabulary, and it was hard to read literature. In her opinion, her real level was B2. According to her, the test was not hard and not easy, but middle. The hardest part of the test was the last section, and the easiest was the first section.

Student $\mathrm{F}$ from the fifth semester self-assessed A1 and reached $\mathrm{C} 1$ in the reading test. She said that since she has no test experience, the reading test result was a surprise, and before joining the test, she thought to be on the A1. Although she believes in the test's efficiency, she believes her real level was B2 instead of C1.

Overall, from the interview results, 3 of them scored themselves at a higher level than what they got from the EF SET test, and the other 3 scored themselves at the lower level. Two of the students that scored themselves in the higher level than what they got from their self-assessment agree that they did not correctly evaluate themselves and that their real level was according to the EF SET Test result. However, one student stated she disagrees with the test result. Her level between B2/C1 instead of A1 got from the test since she can understand articles and literary texts. The students who evaluated themselves at a lower level than what they got from the test result disagreed with the test result since they still lacked the vocabulary and fell hard to understand complex factual and literary texts and abstract, structurally or linguistically complex texts required $\mathrm{C} 1$ or $\mathrm{C} 2$ level. They would choose their real position was B2 Upper Intermediate since the B2 score description fits best what they believe can.

Therefore, according to the reading test result and the students interview, 
they still should improve in their self-assessment and metacognitive awareness, because even with the experience in doing the test and seeing their result, they still do not show awareness about their level on reading skills. In fact, having the skill of metacognition can help the students be more knowledgable and responsible for their cognition (Hermayawati, 2020). This also helps them to explore their critical thinking, since they do not only comprehend the text but they also need to respond and criticize it even having the ability to measure their own capacity in reading particularly. Thus, it can arouse their awareness to learn and improve their ability.

\section{CONCLUSION}

As proposed in this work, a teacher needs to be well prepared to face a classroom and offer teaching quality to his/her students. Furthermore, based on the data analysis and discussion of the finding, most of the English teacher candidates in a private university of Yogayakarta have not yet reached English proficiency. Most of them are not aware yet of their proficiency level. With these results, it is possible to realize that they need to improve their English language proficiency and self-assessment. As discussed in this research, students must be aware of their weaknesses and strengths. After all, it will help them be conscious of how good or bad their learning ability was and improve their learning effectiveness and success in their academic pursuit. This research can be a reference to help develop other research concerns about reading skills and raise awareness in the lectures and responsible for preparing future English teachers.

\section{ACKNOWLEDGEMENTS}

We would like to thank to Universitas Mercu Buana Yogyakarta especially English Language Education Study Program that has facilitated us in conducting this research particularly in gaining the data.

\section{REFERENCES}

Aktifa, A. (2015). The Effect of Think Aloud Strategy on Students 'Reading Achievement of Tenth Grade at Ma Hm Tribakti - Kediri In Academic Year 2014 / 2015 Presented to Nusantara PGRI Kediri University in Partial.

Bui, Tien. (2016, September 1). 2016 International TESOL Conference: FLAMINGOS by Dr Willy A Renandya [Video]. Youtube. https://www.youtube.com/watch? $=$ evxccGaUcFM

Cambridge, U. (2019). Cambridge Assessement in English, 2019. Available at: https://www.cambridgeenglish.org/exams-and-tests/cefr/ (Accessed: 12 November 2019).

Creswell, John W. (2012). Educational Research. 2012,2008,. 501 Boylston Street, Boston, MA 02116: Library of Congress Catalonging-Publication Data.

EF EPI. (2020). EF English Proficiency Index, 2020. Retrieved December 20, 2020, from 2020 website: https://www.ef.sg/epi/regions/asia/

Eslami, Zohreh R. and Fatahi, Azizullah. (2008). 'Teachers' sense of self-efficacy, English proficiency, and instructional strategies: A study of non-native EFL teachers in Iran', Tesl-Ej, 11(4), pp. 1-19.

Hermayawati. (2020). 'Teachers' Efforts in Understanding the Factual, Conceptual, Procedural and Metacognitive Assessment Using the Revised 2013 
Curriculum', International of Learning, Teaching and Educational Research, 19(5), pp 186-199. doi: 10.26803/ijlter.19.5.11

Hughes, A. J. (2019). 'Measuring metacognitive awareness: Applying multiple, triangulated, and mixed-methods approaches for an encompassing measure of metacognitive awareness', Journal of Technology Education, 30(2), pp. 320. doi: 10.21061/jte.v30i2.a.1.

Mcmillion, A. (2009). 'Background Questionnaire for Reading Skills Background Questionnaire for Reading Skills Study reading', pp. 16-18.

Renandya, W. (2018). 'What Kind of English Proficiency is Needed for Effective Teaching?', the Indonesian TESOL Summit, pp. 3-4.

Richards, Jack C. (2015). Key Issues In Language Teaching.2015,. Cambridge: Cambridge University Press Library of Congress Cataloguing-in-Publication Data.

Rivers, M. L., Dunlosky, J. and Persky, A. M. (2020). 'Measuring metacognitive knowledge, monitoring, and control in the pharmacy classroom and experiential settings', American Journal of Pharmaceutical Education, 84(5), pp. 549-560. doi: 10.5688/ajpe7730.

Ross, J. A. (2006). 'The reliability, validity, and utility of self-assessment', Practical Assessment, Research and Evaluation, 11(10).

Tol, C. (2016). The global English language job market is changing, 28 Dec. Available at: https://medium.com/accelerated/the-global-english-languagejob-market-is-changing-what-this-means-for-esl-teachers-92c8d87cf8eb (Accessed: 27 May 2019).

Unesco, I. (2020). Pre-service teacher training, March 2011. Available at: http://uis.unesco.org/en/glossary-term/pre-service-teacher-training (Accessed: 20 January 2020). 